\title{
PEMODELAN JUB DAN BI RATE TERHADAP INFLASI DAN KURS RUPIAH MENGGUNAKAN REGRESI SEMIPARAMETRIK BIRESPON BERDASARKAN ESTIMATOR PENALIZED SPLINE
}

\author{
Siti Fadhilla Femadiyanti ${ }^{1}$, Suparti ${ }^{2}$, Budi Warsito ${ }^{3}$ \\ 1,2,3 Departemen Statistika, Fakultas Sains dan Matematika, Universitas Diponegoro \\ e-mail : suparti702@gmail.com
}

\begin{abstract}
Some indicators of the Indonesian economy are inflation and the exchange rate of rupiah against US dollar. Inflation and the rupiah exchange rate are thought to be influenced by the money supply (JUB) and theBIRate. The money supply has a nonparametric relationship pattern to inflation and therupiah exchange rate, while the BI Rate has a parametric relations hip pattern to inflation and the rupiah exchange rate. The right method for detecting the relationship between inflation and the exchange rate with JUB and BI Rate is birespon semiparametric regres sion with a splined penalized estimator. The semiparametric regression coefficient of bires pon spline penalized is es timated using the Weighted Least square (WLS) method which is determined based on the degree of polynomials, the number and location of the optimal knot points, and the optimal lambda determined based on the minimum of Generalized Cros s Validation (GCV). This research uses the R Program. Based on the results of the analysis, the best spline penalized bires pon semiparametric regression model is located in thenumber of knots is 5 at the knot points of 5257,783; 6649,469;8976,871; 11099,19 and 13535,51 found in the first degree of response is 1 and the second degree of response is 2 with an optimal lambda of 99,99. The results of the performance evaluation of the model produce value of $R^{2}$ is $99,9007 \%$, meaning that the model's performance is very good for out samples of the data and the MAPEvalue of $2.89169 \%$ is less than $10 \%$ which means the model's performance is very good.
\end{abstract}

Keywords: Birespon Spline Penalized Semiparametric Regression, Knot Point, Degrees, Lambda, WLS, GCV.

\section{PENDAHULUAN}

Analisis regresi merupakan suatu metode dalam ilmu statistika yang menganalisis pola hubungan antara variabel respon dan variabel. Terdapat tiga macam pendekatan dalam mengestimasi fungsi regresi, yaitu pendekatan parametrik, nonparametrik, dan semiparametrik. Pada regresi parametrik diasumsikan pola fungsi yang terbentuk antara variabel respon dan variabel prediktor diketahui, sedangkan pada regresi nonparametrik diasumsikan pola fungsi yang terbentuk antara variabel respon dan variabel prediktor tidak diketahui. Apabila pada sebuah model regresi terdapat komponen model yang diestimasi secara parametrik dan komponen lain menggunakan pendekatan nonparametrik terbentuklah model regresi semiparametrik.

Salah satu pendekatan regresi nonparametrik yang cukup populer adalah spline. Spline adalah polinomial yang memiliki sifat tersegmen. Penalized spline adalah salah satu bentuk estimator spline yang diperoleh dengan meminimumkan Penalized Least Square (PLS). Ada beberapa hal yang perlu dipertimbangkan, yaitu titik dan banyaknya knot, fungsi dasar spline, serta derajat dan parameter pemulus lambda. Persoalan dalam kehidupan sehari-hari sering dijumpai pemodelan regresi dengan lebih dari satu variabel respon. Salah satu analisis regresi yang dapat digunakan untuk memodelkan kasus tersebut adalah model regresi birespon. Tujuannya adalah untuk mendapatkan model yang lebih baik dari pemodelan respon tunggal, dengan model regresi yang tidak hanya mempertimbangkan pengaruh prediktor terhadap respon, akan tetapi juga hubungan antar respon.

Beberapa indikator perekonomian Indonesia adalah inflasi dan kurs rupiah. Inflasi dan kurs rupiah saling berkaitan erat. Beberapa faktor yang mempengaruhi inflasi dan nilai tukar atau kurs adalah jub dan suku bunga. Berdasarkan uraian yang telah dijelaskan, penulis 
tertarik untuk membahas secara lebih lanjut mengenai model regresi semiparametrik birespon berdasarkan estimator penalized spline dengan membuat algoritma dan program dalam program $\mathrm{R}$ serta menerapkan hasilnya pada data riil yaitu data inflasi, kurs rupiah terhadap dollar, jumlah uang beredar dan suku bunga dimana suku bunga merupakan komponen prediktor parametrik dan jub merupakan komponen prediktor nonparametrik.

\section{TINJAUAN PUSTAKA}

\subsection{Inflasi}

Menurut Bank Indonesia, inflasi adalah kecenderungan naiknya harga barang dan jasa pada umumnya yang berlangsung secara terus menerus. Perhitungan inflasi dilakukan melalui pendekatan Indeks Harga Konsumen (IHK) sebagai indikator untuk mengukur biaya dari pasar konsumsi barang dan jasa. Jenis inflasi yang digunakan Badan Pusat Statistik (BPS) adalah inflasi bulanan (month to month) dan inflasi tahunan (year on year). 2.2. Kurs

Kurs (exchange rate) adalah harga sebuah mata uang satu negara yang diukur atau dinyatakan dalam mata uang lainnya. Kenaikan harga valuta asing disebut depresiasi sedangkan turunnya harga valuta asing disebut apresiasi. Bank Indonesia memiliki tiga macam kurs yang berlaku, yakni kurs jual, kurs beli, dan kurs tengah.

\subsection{Suku Bunga Indonesia}

Suku Bunga adalah ukuran keuntungan investasi yang dapat diperoleh pemilik modal dan juga merupakan ukuran biaya modal yang harus dikeluarkan oleh perusahaan atas penggunaan dana dari pemilik modal. Kebijakan bunga rendah akan mendorong masyarakat untuk memilih investasi dan konsumsinya daripada menabung, sebaliknya kebijakan meningkatkan suku bunga simpanan akan menyebabkan masyarakat akan lebih senang menabung daripada melakukan investasi atau konsumsi.

\subsection{Jumlah Uang yang Beredar}

Menurut Bank Indonesia, uang beredar dapat didefinisikan dalam arti sempit (M1) dan arti luas (M2). M1 meliputi uang kartal dan uang giral, sedangkan M2 meliputi M1, uang kuasi (mencakup tabungan, simpanan berjangka dalam rupiah dan valas, serta giro dalam valuta asing), dan surat berharga yang diterbitkan oleh sistem moneter yang dimiliki sektor swasta domestik dengan sisa jangka waktu sampai dengan satu tahun.

\subsection{Pendekatan Regresi}

Disamping digunakan untuk mengetahui bentuk hubungan 2 variabel atau lebih, regresi juga dapat digunakan untuk peramalan (Suparti dkk, 2018). Regresi parametrik merupakan pola fungsi regresi yang terbentuk antara variabel respon dan variabel prediktor diketahui (Hardle, 1994). Bentuk regresi parametrik dapat dinyatakan sebagai berikut :

$$
\left[\begin{array}{c}
y_{1} \\
y_{2} \\
\vdots \\
y_{n}
\end{array}\right]=\left[\begin{array}{cccc}
1 & x_{11} & \cdots & x_{1 p} \\
1 & x_{21} & \cdots & x_{2 p} \\
\vdots & \vdots & \ddots & \vdots \\
1 & x_{n 1} & \cdots & x_{n p}
\end{array}\right]\left[\begin{array}{c}
\theta_{0} \\
\theta_{1} \\
\vdots \\
\theta_{p}
\end{array}\right]+\left[\begin{array}{c}
\varepsilon_{1} \\
\varepsilon_{2} \\
\vdots \\
\varepsilon_{n}
\end{array}\right]
$$

Sedangkan bentuk regresi nonparametrik dapat dinyatakan sebagai berikut:

$$
y_{i}=f\left(t_{i}\right)+\varepsilon_{i} ; i=1,2, \ldots, n
$$

dengan $y_{i}$ merupakan variabel respon, $f\left(t_{i}\right)$ adalah persamaan regresi yang tidak diasumsikan mengikuti bentuk tertentu, $t_{i}$ adalah variabel prediktor, sedangkan $\varepsilon_{i}$ adalah error berdistribusi normal independen dengan mean 0 dan variansi $\sigma^{2}$ (Eubank, 1999).

Salah satu metode analisis regresi nonparametrik adalah spline. Menurut Ruppert dkk (2003), truncated power basis derajat $\mathrm{p}$ dan $\mathrm{m}$ knot $\Pi=\left\{k_{1}, k_{2}, \ldots k_{m}\right\}$ dapat dituliskan: 


$$
1, t_{i}, \ldots, t_{i}^{p},\left(t_{i}-k_{1}\right)_{+}^{p}, \ldots,\left(t_{i}-k_{m}\right)_{+}^{p}
$$

Sehingga secara umum fungsi spline dinyatakan sebagai:

$$
f(t)=\alpha_{0}+\alpha_{1} t_{i}+\cdots+\alpha_{p} t_{i}{ }^{p}+\sum_{k=1}^{m} \beta_{m}\left(t_{i}-k_{m}\right)_{+}^{p}
$$

dengan fungsi truncated adalah sebagai berikut:

$$
\left(t_{i}-k_{m}\right)_{+}^{p}= \begin{cases}\left(t_{i}-k_{m}\right)^{p}, & t_{i}>k_{m} \\ 0, & t_{i} \leq k_{m}\end{cases}
$$

Estimator regresi penalized spline diperoleh dengan meminimumkan fungsi Penalized Least Square (PLS) sebagai berikut:

$$
\sum_{i=1}^{n}\left(y_{i}-Z \phi\right)^{2}+\lambda \phi^{T} \boldsymbol{D} \phi, \quad \lambda \geq 0
$$

dimana : $\phi^{\boldsymbol{T}} \boldsymbol{D} \phi=\sum_{k=1}^{m} \phi(p+m)$ dan D menjadi matriks diagonal dengan diagonal pertama $p+1$ adalah 0 dan diagonal lainnya adalah 1 .

$$
D=\left[\begin{array}{cc}
O & 0 \\
O & I_{m}
\end{array}\right]
$$

Suku pertama pada persamaan adalah jumlah kuadrat residual dan suku keduanya adalah penalti kekasaran yang membuat model menjadi lebih halus berdasarkan nilai parameter penghalus $\lambda$ (Ruppert dkk, 2003).

Analisis regresi semiparametrik merupakan gabungan dari regresi parametrik dan regresi nonparametrik. Misalkan terdapat data berpasangan $\left(y_{i}, x_{i}, t_{i}\right)$, dan hubungan antara $y_{i}, x_{i}$ dan $t_{i}$ diasumsikan mengikuti model regresi semiparametrik sebagai berikut:

$$
y_{i}=\theta_{0}+\theta_{1} x_{i}+f\left(t_{i}\right)+\varepsilon_{i} ; \text { dengan } i=1,2, \ldots, n
$$

dengan $y_{i}$ adalah variabel respon pengamatan ke- $i, x_{i}$ adalah komponen parametrik, $f\left(t_{i}\right)$ adalah fungsi regresi nonparametrik dan $\varepsilon_{i}$ adalah residual acak, dengan $\varepsilon \sim \operatorname{IIDN}\left(0, \sigma^{2}\right)$.

\subsection{Regresi Birespon}

Regresi birespon merupakan analisis model regresi yang melibatkan dua variabel respon dalam estimasi data. Model regresi birespon dinyatakan sebagai berikut:

$$
\boldsymbol{y}_{i}=\boldsymbol{f}\left(t_{i}\right)+\boldsymbol{\varepsilon}_{i} ; i=1,2, \ldots, n
$$

dengan $\mathbf{y}_{i}=\left(\mathrm{y}_{i}{ }^{(1)}, \mathrm{y}_{i}{ }^{(2)}\right)^{T}$ adalah dua respon yang saling berkorelasi dan $\mathbf{f}\left(t_{i}\right)=$ (f $\left.\left(t_{i}\right)^{(1)}, \mathrm{f}\left(t_{i}\right)^{(2)}\right)^{T}$ fungsi regresi dalam model, $\boldsymbol{\varepsilon}_{i}=\left(\varepsilon_{i}{ }^{(1)}, \varepsilon_{i}{ }^{(2)}\right)^{T}$ adalah residual pengukuran mean $\mathbf{0}$ dan variansi $\sum_{i}$, dengan matriks variansi-covariansi sebagai berikut : $\sum_{i}=\operatorname{Var}\left(\boldsymbol{\varepsilon}_{i}\right)=\operatorname{Var}\left[\begin{array}{l}\varepsilon_{i}{ }^{(1)} \\ \varepsilon_{i}{ }^{(2)}\end{array}\right]=\left[\begin{array}{cc}\operatorname{Var}\left(\varepsilon_{i}{ }^{(1)}\right) & \operatorname{Cov}\left(\varepsilon_{i}{ }^{(1)}, \varepsilon_{i}{ }^{(2)}\right) \\ \operatorname{Cov}\left(\varepsilon_{i}{ }^{(1)},{ }^{(1)}{ }^{(2)}\right) & \operatorname{Var}\left(\varepsilon_{i}{ }^{(2)}\right)\end{array}\right]=\left[\begin{array}{cc}\sigma_{1 i}^{2} & \sigma_{1 i} \sigma_{2 i} \rho_{i} \\ \sigma_{1 i} \sigma_{2 i} \rho_{i} & \sigma_{2 i}^{2}\end{array}\right]$, dengan $\sigma_{1}^{2}$ dan $\sigma_{2}^{2}$ adalah 2 komponen variansi, dan $\rho_{i}$ merupakan koefisien korelasi (Welsh and Yee, 2006).

\subsection{Estimasi Parameter Weighted Least Square (WLS)}

Pada regresi birespon digunakan metode WLS yang meminimumkan jumlah kuadrat error terboboti dimana dapat digunakan ketika asumsi variansi konstan dalam error dilanggar (Greene, 2003), yang dirumuskan sebagai berikut:

$$
\boldsymbol{\varepsilon}^{T} \boldsymbol{W} \boldsymbol{\varepsilon}=(\boldsymbol{y}-\boldsymbol{Z} \phi)^{T} \boldsymbol{W}(\boldsymbol{y}-\boldsymbol{Z} \phi)
$$

dengan $\phi$ merupakan estimator WLS dan pembobot W merupakan invers dari matrik variansi-kovariansi error respon 1 dan respon 2 sebagai berikut:

$$
\boldsymbol{W}=[\Sigma]^{-1}=\left[\begin{array}{ll}
\Sigma_{11} & \Sigma_{12} \\
\Sigma_{21} & \Sigma_{22}
\end{array}\right]^{-1}
$$

\subsection{Regresi Semiparametrik Bires pon Spline Penalized}

Jika diberikan data berpasangan yang meliputi 2 variabel respon $\left(\mathrm{y}_{i}{ }^{(1)}, \mathrm{y}_{i}{ }^{(2)}\right)$ yang diasumsikan memiliki korelasi antar respon dengan variabel prediktor $x_{i}$ yang diketahui pola hubungannnya dan variabel prediktor $t_{i}$ yang tidak diketahui bentuk pola 
hubungannya. Menurut (Ruppert dkk, 2003) model regresi semiparametrik birespon berdasarkan estimator penalized spline sebagai berikut:

$$
y_{i}^{(r)}=\theta_{0}^{(r)}+\theta_{1}^{(r)} x_{i}+f\left(t_{i}\right)^{(r)}+\varepsilon_{i}^{(r)}
$$

Apabila $f\left(t_{i}\right)^{(r)}$ pada persamaan 13 didekati dengan fungsi spline derajat $\mathrm{p}$ dan $\mathrm{m}$ knot $\Pi=\left\{k_{1}, k_{2}, \ldots, k_{m}\right\}$ maka :

$$
\begin{aligned}
f\left(t_{i}\right)^{(r)}= & \alpha_{0}{ }^{(r)}+\alpha_{1}{ }^{(r)} t_{i}+\alpha_{2}{ }^{(r)} t_{i}{ }^{2} \cdots+\alpha_{p_{r}}{ }^{(r)} t_{i}{ }^{p_{r}}+\beta_{1}{ }^{(r)}\left(t_{i}-k_{1}\right)_{+}^{p_{r}} \\
& +\beta_{2}{ }^{(r)}\left(t_{i}-k_{2}\right)_{+}^{p_{r}}+\cdots+\beta_{m}{ }^{(r)}\left(t_{i}-k_{m}\right)_{+}^{p_{r}}
\end{aligned}
$$

sehingga persamaan menjadi:

$$
\begin{aligned}
y_{i}{ }^{(r)}= & \theta_{0}{ }^{(r)}+\theta_{1}{ }^{(r)} x_{i}+\alpha_{0}{ }^{(r)}+\alpha_{1}{ }^{(r)} t_{i}+\alpha_{2}{ }^{(r)} t_{i}{ }^{2} \cdots+\alpha_{p_{r}}{ }^{(r)} t_{i}{ }^{p_{r}} \\
& +\beta_{1}{ }^{(r)}\left(t_{i}-k_{1}\right)_{+}^{p_{r}}+\beta_{2}{ }^{(r)}\left(t_{i}-k_{2}\right)_{+}^{p_{r}}+\cdots+\beta_{m}{ }^{(r)}\left(t_{i}-k_{m}\right)_{+}^{p_{r}}
\end{aligned}
$$

Menurut (Ruppert dkk, 2003) persamaan 15 dapat ditulis dalam bentuk matriks:

$$
\begin{aligned}
& \boldsymbol{y}=\boldsymbol{X} \boldsymbol{\theta}+Z_{\Pi} \phi_{\Pi}+\boldsymbol{\varepsilon} \\
& {\left[\begin{array}{l}
\boldsymbol{y}^{(1)} \\
\boldsymbol{y}^{(2)}
\end{array}\right]=\left[\begin{array}{cc}
\boldsymbol{X}^{(1)} & \mathbf{0} \\
\mathbf{0} & \boldsymbol{X}^{(2)}
\end{array}\right]\left[\begin{array}{l}
\boldsymbol{\theta}^{(1)} \\
\boldsymbol{\theta}^{(2)}
\end{array}\right]+\left[\begin{array}{cc}
\boldsymbol{Z}_{\Pi}{ }^{(1)} & \mathbf{0} \\
\mathbf{0} & \boldsymbol{Z}_{\Pi}{ }^{(2)}
\end{array}\right]\left[\begin{array}{l}
\phi_{\Pi}{ }^{(1)} \\
\phi_{\Pi}^{(2)}
\end{array}\right]+\left[\begin{array}{l}
\boldsymbol{\varepsilon}^{(1)} \\
\boldsymbol{\varepsilon}^{(2)}
\end{array}\right]}
\end{aligned}
$$

dimana,

$$
\begin{aligned}
& \boldsymbol{\theta}=\left[\begin{array}{l}
\boldsymbol{\theta}^{(1)} \\
\boldsymbol{\theta}^{(2)}
\end{array}\right]=\left[\begin{array}{c}
\theta_{0}^{(1)} \\
\theta_{1}^{(1)} \\
\theta_{0}^{(2)} \\
\theta_{1}^{(2)}
\end{array}\right]_{4 x \mathbf{1}} ; \boldsymbol{Z}_{\Pi}=\operatorname{diag}\left(\boldsymbol{Z}_{\Pi}{ }^{(1)}, \boldsymbol{Z}_{\Pi}{ }^{(2)}\right)=\left[\begin{array}{cc}
\boldsymbol{Z}_{\Pi}{ }^{(1)} & \mathbf{0} \\
\mathbf{0} & \boldsymbol{Z}_{\Pi}{ }^{(2)}
\end{array}\right]_{2 n x\left(p_{1}+p_{2}+2 m+2\right)}
\end{aligned}
$$

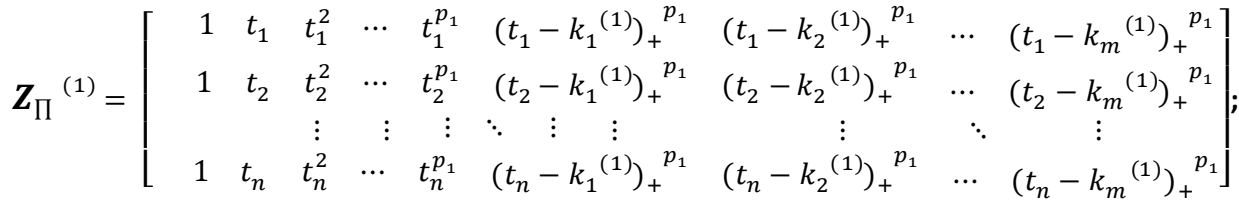

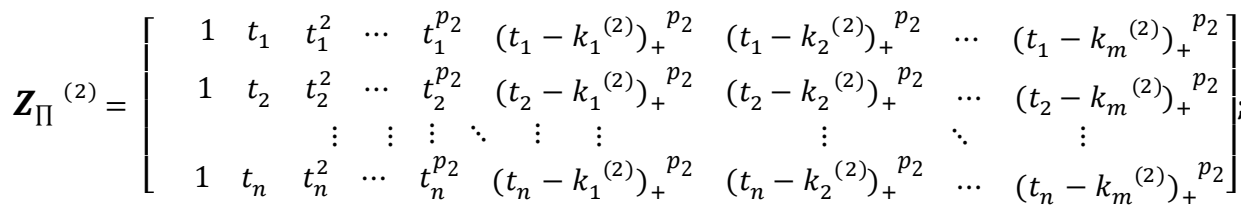

$$
\begin{aligned}
& \boldsymbol{y}=\left[\begin{array}{c}
\boldsymbol{y}^{(1)} \\
\boldsymbol{y}^{(2)}
\end{array}\right]=\left[\begin{array}{c}
y_{1}^{(1)} \\
y_{2}^{(1)} \\
\vdots \\
y_{n}^{(2)} \\
- \\
y_{1}^{(2)} \\
y_{2}^{(2)} \\
\vdots \\
y_{n}^{(2)}
\end{array}\right] \quad ; \boldsymbol{X}=\operatorname{diag}\left(\boldsymbol{X}^{(1)}, \boldsymbol{X}^{(2)}\right)=\left[\begin{array}{cc}
\boldsymbol{X}^{(1)} & \mathbf{0} \\
\mathbf{0} & \boldsymbol{X}^{(2)}
\end{array}\right]=\left[\begin{array}{cccc}
1 & x_{1}^{(1)} & 0 & 0 \\
1 & x_{2}^{(1)} & 0 & 0 \\
\vdots & \vdots & \vdots & \vdots \\
1 & x_{n}^{(1)} & 0 & 0 \\
0 & 0 & 1 & x_{1}^{(2)} \\
0 & 0 & 1 & x_{2}^{(2)} \\
\vdots & \vdots & \vdots & \vdots \\
0 & 0 & 1 & x_{n}^{(2)}
\end{array}\right] \\
& \phi_{\Pi}=\left[\begin{array}{l}
\phi_{\Pi}{ }^{(\mathbf{1})} \\
\phi_{\Pi}{ }^{(2)}
\end{array}\right]=\left[\begin{array}{c}
\boldsymbol{\alpha}^{(\mathbf{1})} \\
\boldsymbol{\beta}^{(1)} \\
\boldsymbol{\alpha}^{(2)} \\
\boldsymbol{\beta}^{(2)}
\end{array}\right]_{2\left(p_{r}+m+1\right) x 1} ; \boldsymbol{\alpha}^{(\mathbf{1})}=\left[\begin{array}{c}
\alpha_{0}^{(1)} \\
\alpha_{1}^{(1)} \\
\alpha_{2}^{(1)} \\
\vdots \\
\alpha_{p}^{(1)}
\end{array}\right] ; \boldsymbol{\alpha}^{(\mathbf{2})}=\left[\begin{array}{c}
\alpha_{0}^{(2)} \\
\alpha_{1}^{(2)} \\
\alpha_{2}^{(2)} \\
\vdots \\
\alpha_{p}^{(2)}
\end{array}\right] ; \boldsymbol{\beta}^{(\mathbf{1})}=\left[\begin{array}{c}
\beta_{1}^{(1)} \\
\beta_{2}^{(1)} \\
\vdots \\
\beta_{m}^{(1)}
\end{array}\right] ; \boldsymbol{\beta}^{(2)}=\left[\begin{array}{c}
\beta_{1}^{(2)} \\
\beta_{2}^{(2)} \\
\vdots \\
\beta_{m}^{(2)}
\end{array}\right]
\end{aligned}
$$




\subsection{Penduga Parameter Semiparametrik}

Pendugaan parameter pada model regresi semiparametrik birespon tidak dapat dilakukan keseluruhan secara simultan sehingga dilakukan dengan 2 tahap. Tahap pertama yaitu menduga parameter komponen nonparametrik terlebih dahulu dengan mengasumsikan $\theta$ diketahui pada persamaan 16. Hasil estimasi fungsi $\boldsymbol{f}(t)$ dengan k knot $\Pi=\left\{k_{1}, k_{2}, \ldots, k_{m}\right\}$ dinyatakan sebagai berikut:

$$
\widehat{\boldsymbol{y}}^{*}=\widehat{\boldsymbol{f}}(\boldsymbol{t})=\boldsymbol{Z}_{\Pi} \widehat{\boldsymbol{\phi}}_{\Pi}
$$

Nilai $\widehat{\phi}_{\Pi}$ didapatkan dengan meminimumkan fungsi Penalized Weighted Least Square:

$$
\boldsymbol{L}=\left(\boldsymbol{y}^{*}-\boldsymbol{z}_{\Pi} \phi_{\Pi}\right)^{\boldsymbol{T}} \boldsymbol{W}\left(\boldsymbol{y}^{*}-z_{\Pi} \phi_{\Pi}\right)+\lambda \phi_{\Pi}{ }^{\boldsymbol{T}} D \phi_{\Pi}
$$

Sehingga didapatkan estimator untuk komponen nonparametrik:

$$
\widehat{\boldsymbol{\phi}}_{\Pi}=\left(\boldsymbol{Z}_{\Pi}{ }^{T} \boldsymbol{W} \boldsymbol{Z}_{\Pi}+\lambda \boldsymbol{D}\right)^{-1} \boldsymbol{Z}_{\Pi}{ }^{T} \boldsymbol{W} \boldsymbol{y}^{*}
$$

Selanjutnya dilanjutkan pada tahap kedua yaitu menduga parameter komponen parametrik. Estimator untuk komponen parametrik yang diperoleh sebagai berikut:

$$
\widehat{\theta}=\left(X^{T}(I-A)^{T}(I-A) X\right)^{-1} X^{T}(I-A)^{T}(I-A) y
$$

Kemudian persamaan 19 dan 20 disubstitusikan dalam persamaan 17, sehingga diperoleh:

$$
\text { dengan } C=X\left(X^{T}(I-A)^{T}(I-A) X\right)^{-1} X^{T}(I-A)^{T}(I-A)
$$

$$
\widehat{y}=C y+Z_{\Pi}\left(Z_{\Pi}{ }^{T} W Z_{\Pi}+\lambda D\right)^{-1} Z_{\Pi}{ }^{T} W(I-C) y
$$

$$
\widehat{\boldsymbol{y}}=A_{\text {par }} \boldsymbol{y}+A_{\text {nonpar }} \boldsymbol{y}=\left(A_{\text {par }}+A_{\text {nonpar }}\right) \boldsymbol{y}=A_{\text {semipar }} y
$$

dengan $A_{\text {par }}=\mathrm{C}$ dan $A_{\text {nonpar }}=A(I-C)$ dan $A_{\text {semipar }}$ merupakan matriks penghalus yang sesuai untuk variabel respon disetiap pengamatan (Wu \& Zhang, 2006).

\subsection{Pemilihan Banyaknya Titik Knotdan Lambda Optimal}

Pada penalized spline, knot terletak pada sampel kuantil dari nilai unique tunggal, dengan knot ke-k adalah kuantil ke-j dari nilai unique dimana $\mathrm{j}=\mathrm{k} /(1+\mathrm{m})$. Parameter $\lambda$ merupakan pengontrol keseimbangan antara kemulusan fungsi terhadap data. Salah satu metode yang digunakan sebagai kriteria menentukan parameter $\lambda$ dan titik knot optimal adalah dengan menentukan nilai Generalized Cross Validation (GCV) sebagai berikut:

\subsection{Uji Linieritas}

$$
\operatorname{GCV}(\lambda)=\frac{\frac{1}{N} \sum_{j=1}^{2} \sum_{i=1}^{n}\left(y_{i}^{(r)}-\hat{y}_{i}^{(r)}\right)^{2}}{\left(1-(N)^{-1} \operatorname{tr}(A(\lambda))\right)^{2}}
$$

Pada penelitian ini memiliki dua variabel respon, sehingga dalam melakukan uji linieritas dilakukan menggunakan regresi multivariat. Regresi multivariat adalah regresi dengan lebih dari satu variabel respon yang saling berkorelasi dan satu atau lebih variabel prediktor (Johnson dan Wichern, 2007). Statistik uji yang digunakan adalah Wilk's Lambda, F hitung, dan nilai signifikansi pada tabel MANOVA. Menurut (Riskiyanti, 2007) nilai Wilk's Lambda dapat dihitung dengan sebaigai berikut:

$$
\Lambda=\frac{\left|Y^{T} Y-\theta X^{T} Y\right|}{\left|Y^{T} Y-n \bar{y} \bar{y}^{T}\right|}
$$

dengan daerah kritis $\mathrm{H} 0$ ditolak apabila signifikansi kurang dari alfa $5 \%$ atau $\mathrm{F}$ hitung lebih besar dari $\mathrm{F}$ tabel, sehingga dapat disimpulkan bahwa terdapat hubungan linier secara signifikan antara variabel respon dengan variabel prediktor, begitu pula sebaliknya.

\subsection{Uji Korelasi Pearson}

Uji korelasi Pearson dilakukan untuk mengetahui ada tidaknya korelasi antara kedua variabel respon. Menurut Supranto (1988), nilai koefisien:

$$
r=\frac{n\left(\sum_{i=1}^{n} y_{i}^{(1)} y_{i}^{(2)}\right)-\left(\sum_{i=1}^{n} y_{i}^{(1)}\right)\left(\sum_{i=1}^{n} y_{i}^{(2)}\right)}{\sqrt{\left(n \sum_{i=1}^{n}\left(y_{i}^{(1)}\right)^{2}-\left(\sum_{i=1}^{n} y_{i}^{(1)}\right)^{2}\right)\left(n \sum_{i=1}^{n}\left(y_{i}^{(2)}\right)^{2}-\left(\sum_{i=1}^{n} y_{i}^{(2)}\right)^{2}\right)}}
$$


Nilai $\mathrm{r}$ berada diantara -1 sampai $1(-1 \leq r \leq 1)$. Nilai $r=1$ disebut dengan korelasi linier positif sempurna, nilai $r=-1$ disebut dengan korelasi linier negatif sempurna, sedangkan apabila $r=0$ menunjukan bahwa tidak terdapat korelasi antara kedua variabel tersebut.

\subsection{Ketepatan Metode Peramalan}

Kinerja model yang digunakan dalam peramalan dapat dilihat berdasarkan nilai $R^{2}$ dan Mean Absolute Percentage Error (MAPE). $R^{2}$ digunakan untuk mengukur seberapa besar persentase keragaman dalam variabel respon yang dijelaskan oleh variabel prediktor. Nilai $R^{2}$ berada pada kisaran $0 \leq R^{2} \leq 1$ (Gujarati, 2006). Rumus $R^{2}$ sebagai berikut:

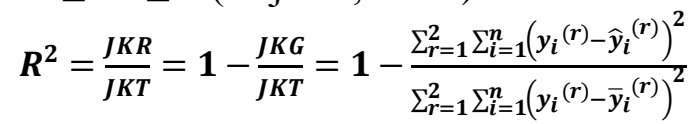

MAPE merupakan rata-rata dari keseluruhan persentase kesalahan (selisih) antara data aktual dengan hasil peramalan. Perhitungan nilai MAPE adalah sebagai berikut:

\section{METODE PENELITIAN}

$$
M A P E=\frac{1}{N} \sum_{r=1}^{2} \sum_{i=1}^{n} \frac{\left|y_{i}{ }^{(r)}-\hat{y}_{i}{ }^{(r)}\right|}{y_{i}{ }^{(r)}} \times 100 \%
$$

Data yang digunakan merupakan data sekunder yaitu data inflasi (\%), kurs (ribu rupiah), JUB (triliun lembar), dan suku bunga (\%) yang bersumber dari website http:/www.bi.go.id. Data in-sample digunakan dalam pembentukan model terhitung sejak triwulan 4 tahun 2006 sampai triwulan 4 tahun 2017 sebanyak 45 data. Data out-sample digunakan untuk evaluasi kinerja model terhitung sejak triwulan 1 tahun 2018 sampai triwulan 1 tahun 2019. Berikut adalah langkah-langkah analisis data:

1. Menginputkan data berpasangan $\left(y_{i}^{r}, x_{i}, t_{i}\right)$ dimana $i=1,2, \ldots, n ; r=1,2$

2. Membuat scatterplot antara variabel respon dengan variabel prediktor

3. Melakukan uji linieritas untuk variabel prediktor komponen parametrik

4. Menguji korelasi Pearson antara variabel respon 1 dan respon 2

5. Mengestimasi tanpa matrik pembobot (W) dengan langkah-langkah sebagai berikut :

a. Mendefinisikan sampel kuantil dari nilai $t$ yang diurutkan dari nilai terkecil ke nilai yang terbesar untuk pemilihan titik knot.

b. Menentukan titik knot $\mathrm{k}=1,2,3,4,5$.

c. Mencari lambda optimal diantara 1-2000 yang meminimalkan GCV di setiap kombinasi derajat pada masing-masing titik knot. Kemudian memilih titik knot dan derajat yang meminimalkan GCV

d. Menentukan matrik A dengan menggunakan parameter smoothing.

e. Melakukan estimasi model tanpa pembobot W menggunakan parameter smoothing

f. Memperoleh nilai $\hat{\boldsymbol{\varepsilon}}$ untuk respon 1 dan respon 2 dari hasil estimasi.

6. Mendefinisikan matrik pembobot $\mathrm{W}$

7. Mengestimasi menggunakan matrik pembobot (W) dengan langkah sebagai berikut :

a. Menggunakan titik knot dan derajat yang sebelumnya di dapatkan pada langkah 5 .

b. Menentukan matrik A dengan menggunakan parameter smoothing optimal

c. Melakukan estimasi model dan membuat plot data asli dan hasil estimasinya.

d. Menghitung nilai R-square dan MAPE.

\section{HASIL DAN PEMBAHASAN}

\subsection{Penentuan Variabel Prediktor Komponen Parametrik dan Non Parametrik}

Penentuan variabel prediktor dilakukan dengan cara melihat scatterplot data pada masing masing variabel respon dan variabel prediktor. 


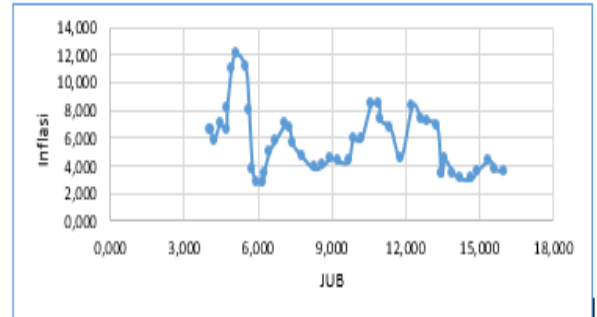

Gambar 1. Scatterplot antara $y^{(1)}$ dengan $t$

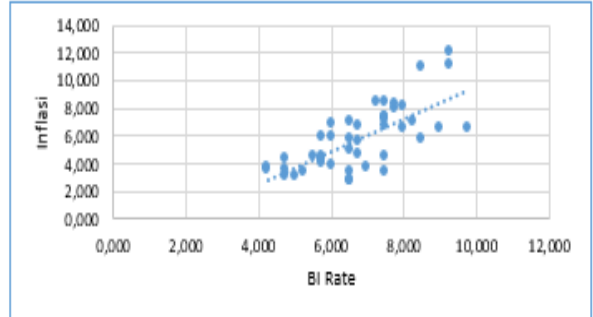

Gambar 3. Scatterplot antara $y^{(1)}$ dengan $x$

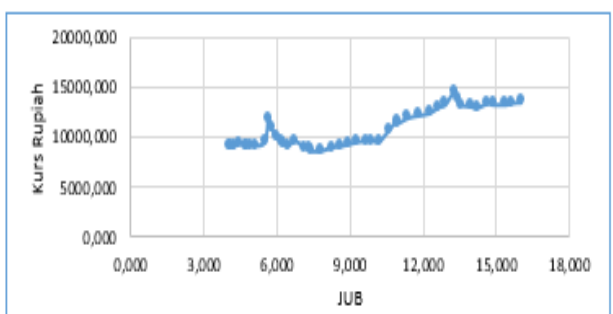

Gambar 2. Scatterplot antara $y^{(2)}$ dengan $t$

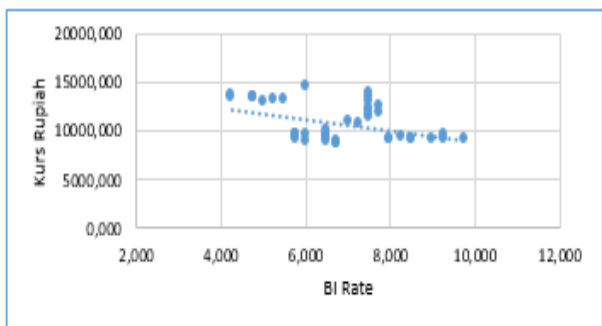

Gambar 4. Scatterplot antara $y^{(2)}$ dengan $x$

Berdasarkan dari Gambar 1, 2, 3, dan 4 diketahui bahwa pada variabel respon $y^{(1)}$ dan $y^{(2)}$ dengan variabel prediktor $t$, plot data tidak mengikuti pola tertentu dan cenderung terjadi naik turun data, sehingga disimpulkan bahwa $t$ merupakan variabel nonparametric. Sedangkan pada data variabel respon $y^{(1)}$ dan $y^{(2)}$ dengan variabel prediktor $x$ plot data cenderung mengikuti pola linier sehingga dapat dikatakan merupakan variabel parametrik.

\subsection{Uji Linie ritas untuk Variabel Pre diktor Komponen Parametrik}

Berdasarkan Tabel MANOVA didapakan nilai sig $=0,000$ kurang dari $\alpha=0,05$ atau $\mathrm{F}$ hitung $=5,109$ lebih besar dari $\mathrm{F}$ tabel $=1,647561265$, sehingga $H_{0}$ ditolak. Jadi pada taraf signifikansi $\alpha=5 \%$ dapat dikatakan bahwa terdapat hubungan linier secara signifikan antara $y^{(1)}$ (inflasi) dan $y^{(2)}$ (kurs rupiah) terhadap $x$ (BI rate).

\subsection{Uji Korelasi Pada Variabel Respon}

Berdasarkan statisitik uji didapatkan nilai $r=-0,4891515, t=-3,677579878<$ $-t_{(\alpha / 2, v)}=-2,016692199$ dan p-value $0,016<\alpha=0,05$ sehingga H0 ditolak. Jadi pada taraf signifikansi $5 \%$, dapat disimpulkan bahwa variabel respon $y^{(1)}$ dan $y^{(2)}$ memiliki korelasi sehingga penelitian ini dapat dilanjutkan dengan menggunakan analisis regresi birespon.

\subsection{Estimasi Model (tanpa Pembobot)}

Langkah selanjutnya adalah menentukan derajat polinomial optimal respon 1 dan respon 2 serta banyaknya titik knot optimal dengan mendapatkan nilai lambda optimal pada variabel prediktor komponen nonparametrik menggunakan program yang telah dibuat.

Tabel 1.Tabel GCV pada Banyaknya Knot 1,2,3,4,5

\begin{tabular}{cccccc}
\hline \multirow{2}{*}{$\begin{array}{c}\text { Banyak } \\
\text { Knot }\end{array}$} & Titik Knot & \multicolumn{2}{c}{ Kombinasi Derajat } & \multirow{2}{*}{ GCV } & Lambda \\
& & 1 & 2 & & \\
& & 1 & 1 & $\mathbf{3 . 5 5 7 3 4}$ & $\mathbf{1 9 9 1}$ \\
\multirow{3}{*}{1} & 8976.871 & 1 & 2 & 3.85747 & 1937 \\
& & 2 & 1 & 3.581978 & 1937 \\
& & 2 & 2 & 3.894624 & 356 \\
\hline \hline
\end{tabular}


ISSN: 2339-2541

JURNAL GAUSSIAN, Volume 9, Nomor 2, Tahun 2020, Halaman 215-227 Online di: https://ejournal3.undip.ac.id/index.php/gaussian/

$5974.754 ; 8976.871 ; 12639.31$

4

$5633.591 ; 7382.82 ; 10357.6 ; 13317.15$

$5974.754 ; 8976.871 ; 12639.31$
$6649.469 ; 11099.19$

257.783; 6649.469; 8976.871; 11099.19;

13535.51
$4.000209 \quad 1991$

$3.872542 \quad 112$

$3.814953 \quad 112$

$\mathbf{3 . 6 5 6 9 8} 112$

$3.869055 \quad 1991$

$3.988201 \quad 1923$

$3.63558 \quad 1923$

$3.742407 \quad 1923$

$3.855085 \quad 1991$

$4.234572 \quad 1756$

$3.26838 \quad 1996$

$3.66774 \quad 1041$

$3.856367 \quad 1991$

$\mathbf{0 . 2 2 5 8 4} 1305$

$3.415027 \quad 1993$

$2.7388 \quad 1305$

Berdasarkan Tabel 1 dapat dilihat bahwa:

1. Pada banyaknya knot adalah 1 nilai GCV minimum sebesar 3,557340 terletak pada derajat respon 1 adalah 1, derajat respon 2 adalah 1, dan lambda optimal sebesar 1991.

2. Pada banyaknya knot adalah 2 nilai GCV minimum sebesar 3,656984 terletak pada derajat respon 1 adalah 2, derajat respon 2 adalah 2, dan lambda optimal sebesar 112.

3. Pada banyaknya knot adalah 3 nilai GCV minimum sebesar 3,635576 terletak pada derajat respon 1 adalah 2, derajat respon 2 adalah 1, dan lambda optimal sebesar 1923.

4. Pada banyaknya knot adalah 4 nilai GCV minimum sebesar 3,268375 terletak pada derajat respon 1 adalah 2, derajat respon 2 adalah 1, dan lambda optimal sebesar 1996.

5. Pada banyaknya knot adalah 5 nilai GCV minimum sebesar 0,2258413 terletak pada derajat respon 1 adalah 2, derajat respon 2 adalah 1 dan lambda optimal sebesar 1305.

\subsection{Pemilihan Derajat Respon, Banyaknya Knot, Titik Knot, dan Lamda Optimal}

Pemilihan derajat respon, banyaknya titik knot, titik knot, dan lambda optimal dilakukan dengan melihat nilai GCV terkecil. Nilai GCV optimal dari setiap model pada banyaknya knot 1,2,3,4, dan 5 adalah sebagai berikut:

Tabel 2. Perbandingan Nilai GCV Optimal

\begin{tabular}{cccccc}
\hline $\begin{array}{c}\text { Banyak } \\
\text { Knot }\end{array}$ & Titik Knot & \multicolumn{2}{c}{ Kombinasi Derajat } \\
Respon & Respon & GCV & Rinimum & Lambda \\
& & 1 & 2 & & \\
\hline 1 & 8976.87 & 1 & 1 & 3.55734 & 1991 \\
2 & $6649.469 ; 11099.19$ & 2 & 2 & 3.656984 & 112 \\
3 & $5974.754 ; 8976.871 ; 12639.31$ & 2 & 1 & 3.635576 & 1923 \\
4 & $5633.591 ; 7382.82 ; 10357.6 ; 13317.15$ & 2 & 1 & 3.268375 & 1996 \\
& $5257.783 ; 6649.469 ; 8976.871 ;$ & & & & \\
5 & $11099.19 ;$ & 1 & 2 & $\mathbf{0 . 2 2 5 8 4}$ & $\mathbf{1 3 0 5}$ \\
& 13535.51 & & & & \\
\hline
\end{tabular}

Berdasarkan Tabel 2 didapatkan nilai GCV minimum yang paling kecil yaitu 0,225841 terletak pada banyaknya titik knot sebanyak 5 di titik knot 5257,783; 6649,469; 8976,871; 11099,19 dan 13535,51 dengan nilai lambda optimal 1305 terdapat pada derajat 
respon 1 adalah 1 dan derajat respon 2 adalah 2. Setelah didapatkan kombinasi derajat polinomial respon 1 dan respon 2 serta banyaknya titik knot, dan titik knot optimal maka dilakukan pemodelan berdasarkan kombinasi derajat polinomial respon 1 dan respon 2 serta banyaknya titik knot, dan titik knot optimal dengan lambda optimal pada saat GCV minimum adalah 1329,2 dengan nilai $R^{2}=90,4661 \%$ dan $M S E=0,991199$, sehingga didapatkan nilai residual dari respon 1 dan respon 2. Model tersebut memiliki persamaan :

* Model regresi pada respon 1

$$
\begin{aligned}
y_{i}^{(1)}= & \theta_{0}^{(1)}+\theta_{1}^{(1)} x_{i}+\alpha_{0}{ }^{(1)}+\alpha_{1}{ }^{(1)} t_{i}+\beta_{1}{ }^{(1)}\left(t_{i}-k_{1}\right)_{+}^{1}+\beta_{2}{ }^{(1)}\left(t_{i}-k_{2}\right)_{+}^{1} \\
& +\beta_{3}{ }^{(1)}\left(t_{i}-k_{3}\right)_{+}^{1}+\beta_{4}{ }^{(1)}\left(t_{i}-k_{4}\right)_{+}^{1}+\beta_{5}{ }^{(1)}\left(t_{i}-k_{5}\right)_{+}^{1}+\varepsilon_{i}^{(1)}
\end{aligned}
$$

Model regresi pada respon 2

$$
\begin{aligned}
y_{i}^{(2)}= & \theta_{0}{ }^{(2)}+\theta_{1}^{(2)} x_{i}+\alpha_{0}{ }^{(2)}+\alpha_{1}{ }^{(2)} t_{i}+\alpha_{2}{ }^{(2)}{t_{i}}^{2}+\beta_{1}{ }^{(2)}\left(t_{i}-k_{1}\right)_{+}^{2}+\beta_{2}{ }^{(2)} \\
& \left(t_{i}-k_{2}\right)_{+}^{2}+\beta_{3}{ }^{(2)}\left(t_{i}-k_{3}\right)_{+}^{2}+\beta_{4}{ }^{(2)}\left(t_{i}-k_{4}\right)_{+}^{2}+\beta_{5}{ }^{(2)}\left(t_{i}-k_{5}\right)_{+}^{2}+\varepsilon_{i}^{(2)}
\end{aligned}
$$

\subsection{Estimasi Model (dengan Pembobot)}

Langkah berikutnya adalah mengestimasi model regresi semiparametrik birespon berdasarkan estimator penalized spline menggunakan pembobot $\mathrm{W}$ dengan program yang telah dibuat. Estimasi model menggunakan pembobot $\mathrm{W}$ dilakuakan dengan menggunakan derajat polinomial respon 1 dan respon 2 serta banyaknya titik knot, dan titik knot optimal yang sebelumnya telah didapatkan yaitu banyaknya titik knot sebanyak 5 di titik knot 5257,783; 6649,469; 8976,871; 11099,19 dan 13535,51 dengan derajat respon 1 adalah 1 dan derajat respon 2 adalah 2.Berdasarkan percobaan yang dilakukan diperoleh lambda optimal 99,99 dengan nilai GCV minimum sebesar 4,167394. Langkah selanjutnya adalah diperoleh model regresi semiparametrik birespon berdasarkan estimator penalized spline dimana telah didapatkan estimasi parameter menggunakan pembobot $\mathrm{W}$.

Berdasarkan estimasi model respon 1 yang didapatkan dengan model regresi semiparametrik birespon berdasarkan estimator penalized spline dengan lambda optimal 99,99 serta derajat respon 1 adalah 1 , dan banyaknya knot $=5$ adalah sebagai berikut:

$$
\begin{aligned}
y_{i}^{(1)}= & \theta_{0}{ }^{(1)}+\theta_{1}^{(1)} x_{i}+\alpha_{0}{ }^{(1)}+\alpha_{1}{ }^{(1)} t_{i}+\beta_{1}{ }^{(1)}\left(t_{i}-k_{1}\right)_{+}^{1}+\beta_{2}{ }^{(1)}\left(t_{i}-k_{2}\right)_{+}^{1} \\
& +\beta_{3}{ }^{(1)}\left(t_{i}-k_{3}\right)_{+}{ }_{+}+\beta_{4}{ }^{(1)}\left(t_{i}-k_{4}\right)_{+}^{1}+\beta_{5}{ }^{(1)}\left(t_{i}-k_{5}\right)_{+}^{1}+\varepsilon_{i}^{(1)}
\end{aligned}
$$

Berdasarkan estimasi model respon 2 yang didapatkan dengan model regresi semiparametrik birespon berdasarkan estimator penalized spline dengan lambda optimal 99,99 serta derajat respon 2 adalah 2, dan banyaknya knot $=5$ adalah sebagai berikut:

$$
\begin{aligned}
y_{i}^{(2)}= & \theta_{0}{ }^{(2)}+\theta_{1}^{(2)} x_{i}+\alpha_{0}{ }^{(2)}+\alpha_{1}{ }^{(2)} t_{i}+\alpha_{2}{ }^{(2)} t_{1}{ }^{2}+\beta_{1}{ }^{(2)}\left(t_{i}-k_{1}\right)_{+}^{2}+\beta_{2}{ }^{(2)} \\
& \left(t_{i}-k_{2}\right)_{+}{ }_{+}+\beta_{3}{ }^{(2)}\left(t_{i}-k_{3}\right)_{+}{ }_{+}+\beta_{4}{ }^{(2)}\left(t_{i}-k_{4}\right)_{+}^{2}+\beta_{5}{ }^{(2)}\left(t_{i}-k_{5}\right)_{+}{ }^{2}+\varepsilon_{i}^{(2)}
\end{aligned}
$$

Hasil nilai estimasi parameter penalized spline respon 1 sebagai berikut:

$$
\begin{aligned}
y_{i}^{(1)}= & -0,00000000069978+1,734103 x_{i}-23,28087+0,003477961 t_{i}-0,005000597 \\
& \left(t_{i}-5257,783\right)_{+}^{1}+0,00235107\left(t_{i}-6649,469\right)_{+}^{1}-0,000928352\left(t_{i}-8976,871\right)_{+}^{1} \\
& -0,0002501766\left(t_{i}-11099,19\right)_{+}^{1}+0,00148251\left(t_{i}-13535,51\right)_{+}^{1}+\varepsilon_{i}^{(1)}
\end{aligned}
$$

Hasil nilai estimasi parameter penalized spline respon 2 sebagai berikut:

$y_{i}^{(2)}=-0,00000006415737+0,2560038 x_{i}+9,993754-0,002139017 t_{i}$

$$
\begin{aligned}
& +0,0000003275896 t_{1}{ }^{2}-0,00000125662\left(t_{i}-5257,783\right)_{+}^{2}+0,00000142106 \\
& \left(t_{i}-6649,469\right)^{2}-0,000000501655\left(t_{i}-8976,871\right)_{+}^{2}-0,00000003488845 \\
& \left(t_{i}-11099,19\right)_{+}^{\frac{1}{2}}-0,0000001822905\left(t_{i}-13535,51\right)_{+}^{2}+\varepsilon_{i}^{(2)}
\end{aligned}
$$


Berdasarkan persamaan didapatkan fungsi nonparametrik berdasarkan estimator penalized spline serta dapat diinterprestasikan secara lebih mudah dalam bentuk fungsi potongan. Fungsi potongan untuk respon 1 yaitu inflasi dinyatakan pada persamaan sebagai berikut:

$$
f\left(t_{i}\right)^{(1)}=\left\{\begin{aligned}
-23,28087+0,003477961 t_{i}, & 0 \leq t_{i}<5257,783 \\
-23,28087+0,00347796 t_{i}-0,005000597\left(t_{i}-5257,783\right), & 5257,783 \leq t_{i}<6649,469 \\
-23,28087+0,00347796 t_{i}-0,005000597\left(t_{i}-5257,783\right), & 6649,469 \leq t_{i}<8976,871 \\
+0,002351066\left(t_{i}-6649,469\right) & \\
-23,28087+0,00347796 t_{i}-0,005000597\left(t_{i}-5257,783\right) & \\
+0,00235107\left(t_{i}-6649,469\right)-0,00092835\left(t_{i}-8976,871\right) & 8976,871 \leq t_{i}<11099,19 \\
-23,28087+0,00347796 t_{i}-0,005000597\left(t_{i}-5257,783\right) & \\
+0,00235107\left(t_{i}-6649,469\right)-0,00092835\left(t_{i}-8976,871\right), & 11099,19 \leq t_{i}<13535,51 \\
-0,0002501766\left(t_{i}-11099,19\right) & \\
-23,28087+0,00347796 t_{i}-0,005000597\left(t_{i}-5257,783\right) & \\
+0,00235107\left(t_{i}-6649,469\right)-0,0009284\left(t_{i}-8976,871\right), & t_{i} \geq 13535,5 \\
-0,000250177\left(t_{i}-11099,19\right)+0,001483\left(t_{i}-13535,51\right) &
\end{aligned}\right.
$$

Berdasarkan potongan polinomial terlihat bahwa inflasi dipengaruhi oleh JUB pada 6 segmen yang berbeda dan tetap kontinue, yaitu ketika JUB diantara 0 sampai 5257,783; JUB diantara 5257,783 sampai 6649,469; JUB diantara 6649,469 sampai 8976,871; JUB diantara 8976,871 sampai 11099,19; JUB diantara 11099,19 sampai 13535,51; dan JUB lebih besar dari 13535,5.

Berdasarkan persamaan didapatkan fungsi nonparametrik berdasarkan estimator spline penalized serta dapat diinterprestasikan secara lebih mudah dalam bentuk fungsi potongan. Fungsi potongan untuk respon 2 yaitu kurs rupiah dinyatakan pada persamaan sebagai berikut:

$$
f\left(t_{i}\right)^{(2)}=\left\{\begin{array}{cc}
9,993754-0,002139017 t_{i}+0,0000003275896 t_{1}{ }^{2}, & 0 \leq t_{i}<5257,783 \\
9,993754-0,002139017 t_{i}+0,0000003275896 t_{1}{ }^{2}, & 5257,783 \leq t_{i}<6649,469 \\
-0,000001256615\left(t_{i}-5257,783\right) & \\
9,993754-0,002139017 t_{i}+0,0000003275896 t_{1}{ }^{2} & \\
-0,000001256615\left(t_{i}-5257,783\right) & \\
+0,00000142106\left(t_{i}-6649,469\right) & \\
9,993754-0,002139017 t_{i}+0,0000003275896 t_{1}{ }^{2} & \\
-0,000001256615\left(t_{i}-5257,783\right) & \\
+0,000000142106\left(t_{i}-6649,469\right) & \\
+0,00000142106\left(t_{i}-6649,469\right) & \\
-0,000000501655\left(t_{i}-8976,871\right) & \\
-0,00000003488845\left(t_{i}-11099,19\right)^{2} & \\
-0,000001256615\left(t_{i}-5257,783\right) & \\
+0,00000142106\left(t_{i}-6649,469\right) & \\
-0,000000501655\left(t_{i}-8976,871\right) & \\
-0,00000003488845\left(t_{i}-11099,19\right)^{2} & \\
-0,0000001822905\left(t_{i}-13535,51\right)^{2} &
\end{array}\right.
$$

Berdasarkan potongan polinomial terlihat bahwa kurs rupiah dipengaruhi oleh JUB pada 6 segmen yang berbeda dan tetap kontinue, yaitu ketika JUB diantara 0 sampai 5257,783; JUB diantara 5257,783 sampai 6649,469; JUB diantara 6649,469 sampai 8976,871; JUB 
diantara 8976,871 sampai 11099,19; JUB diantara 11099,19 sampai 13535,51; dan JUB lebih besar dari 13535,5.

Berdasarkan estimasi model didapatkan nilai $R^{2}=90,9606 \%$ dan $M S E=$ 0,93912 . Nilai $R^{2}$ dan $M S E$ dengan menggunakan pembobot ini lebih besar dibanding nya dengan nilai $R^{2}$ dan $M S E$ tanpa menggunakan pembobot, sehingga pada penelitian ini dapat dikatakan cocok untuk menggunakan estimasi Weigted Least Square. Nilai estimasi serta plot estimasi yang dihasilkan ketika nilai estimasi tersebut dikembalikan terhadap waktu dapat dilihat sebagai berikut:
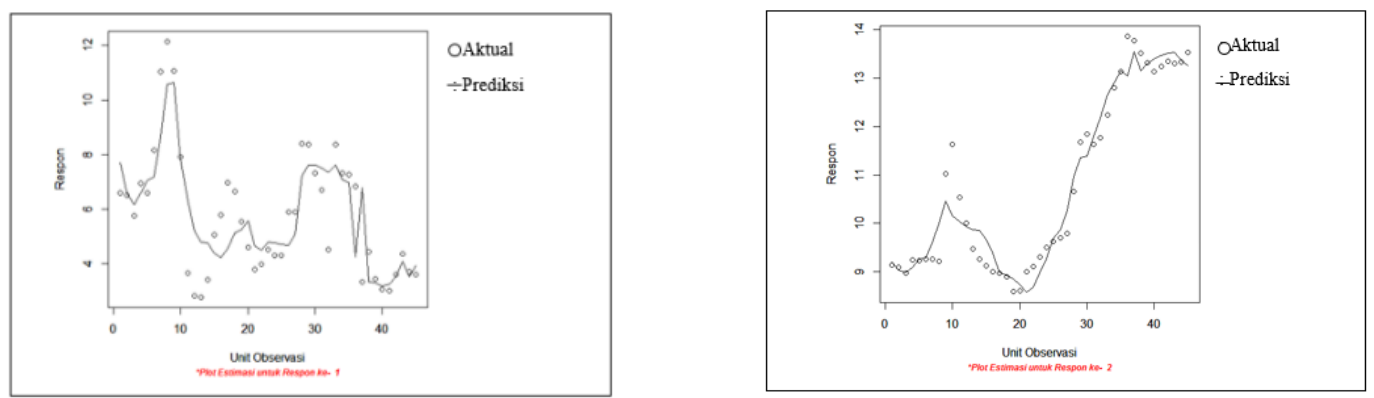

Gambar 5. Plot Estimasi untuk Respon 1 Gambar 6. Plot Estimasi untuk Respon 2

Berdasarkan Gambar 5 dan Gambar 6 terlihat bahwa nilai data aktual dan hasil prediksi tidak jauh berbeda. Hal ini menujukan bahwa model regresi semiparametrik birespon berdasarkan estimator penalized spline optimal yang diperoleh merupakan hasil pemilihan derajat, banyaknya knot dan parameter penghalus lambda yang paling optimal sehingga menghasilkan GCV paling minimum.

\subsection{Perbandingan Hasil Prediksi dengan Data Asli Out-sample}

Perbandingan data inflasi dan kurs pada triwulan 1 tahun 2018 sampai triwulan 1 tahun 2019 dan data kurs prediksi yang diperoleh dari model tertera pada Tabel 3.

Tabel 3. Perbandingan Data dan Hasil Prediksi

\begin{tabular}{ccccc}
\hline & & \multicolumn{2}{c}{ Inflasi } & \multicolumn{2}{c}{$\begin{array}{c}\text { Kurs Rupiah } \\
\text { (ribuan) }\end{array}$} \\
Periode & $\begin{array}{c}\text { Data Inflasi } \\
\text { Asli }\end{array}$ & Inflasi Hasil Prediksi & $\begin{array}{c}\text { Data } \\
\text { Kurs } \\
\text { Rupiah } \\
\text { Asli }\end{array}$ & $\begin{array}{c}\text { Kurs } \\
\text { Rupiah } \\
\text { Hasil } \\
\text { Prediksi }\end{array}$ \\
\hline Triwulan 1 2018 & 3.4 & 34.13817 & 13.75600 & 13.76250 \\
Triwulan 2 2018 & 3.12 & 30.94955 & 14.40400 & 14.40769 \\
Triwulan 3 2018 & 2.88 & 28.58419 & 14.92900 & 14.87245 \\
Triwulan 4 2018 & 3.13 & 28.20444 & 14.48100 & 14.27872 \\
Triwulan 1 2019 & 2.48 & 28.22366 & 14.12775 & 14.37640 \\
\hline
\end{tabular}

Berdasarkan Tabel 3 terlihat bahwa nilai data asli dan hasil prediksi tidak jauh berbeda. Hal ini menujukan bahwa model regresi semiparametrik birespon berdasarkan estimator penalized spline yang diperoleh merupakan hasil pemilihan derajat, banyaknya knot dan parameter penghalus lambda yang optimal sehingga menghasilkan GCV paling minimum. 


\subsection{Evaluasi Kinerja Model}

Kinerja model yang digunakan dalam peramalan dapat dilihat berdasarkan nilai koefisien determinasi $\left(R^{2}\right)$ dan Mean Absolute Percentage Error (MAPE). Nilai $R^{2}$ dapat dinyatakan sebagai berikut:

$$
R^{2}=\frac{J K R}{J K T}=1-\frac{J K G}{J K T}=1-\frac{\sum_{r=1}^{2} \sum_{i=1}^{n}\left(y_{i}{ }^{(r)}-\hat{y}_{i}{ }^{(r)}\right)^{2}}{\sum_{r=1}^{2} \sum_{i=1}^{n}\left(y_{i}{ }^{(r)}-\bar{y}_{i}{ }^{(r)}\right)^{2}}=0,999007
$$

Berdasarkan perhitungan tersebut diperoleh nilai $R^{2}$ yang sangat tinggi yaitu sebesar $99,9007 \%$, artinya bahwa kinerja model sangat baik untuk data out sample.

MAPE merupakan rata-rata dari keseluruhan persentase kesalahan (selisih) antara data aktual dengan hasil peramalan. Perhitungan nilai MAPE adalah sebagai berikut:

$$
\text { MAPE }=\frac{1}{N} \sum_{r=1}^{2} \sum_{i=1}^{n} \frac{\left|y_{i}^{(r)}-\hat{y}_{i}^{(r)}\right|}{y_{i}^{(r)}} \times 100 \%=2,89169 \%
$$

Berdasarkan perhitungan yang telah dilakukan diperoleh nilai MAPE sebesar 2,89169\%. Nilai MAPE 2,89169\% kurang dari 10\% yang berarti kinerja model sangat baik.

\section{KESIMPULAN}

Model Semiparametrik birespon berdasarkan estimator penalized spline terbaik yang diperoleh adalah dengan nilai GCV minimum yang paling kecil yaitu 4,167394 terletak pada banyaknya titik knot sebanyak 5 di titik knot 5257,783; 6649,469; 8976,871; 11099,19 dan 13535,51 dengan nilai lambda optimal sebesar 99,99 yang terdapat pada derajat respon 1 adalah 1 dan derajat respon 2 adalah 2. Nilai ketetapan model terbaik dapat dilihat dari besarnya nilai koefisien determinasi $R^{2}$ dan MAPE. Berdasarkan perhitungan diperoleh nilai $R^{2}$ pada data in-sample sebesar $99,9606 \%$ dan pada data out-sample sebesar $99,9007 \%$. Karena nilai $R^{2}$ in-sample dan $R^{2}$ out-sample mendekati $100 \%$, artinya bahwa kinerja model sangat baik. Nilai MAPE yang didapatkan dalam perhitungan sebesar 2,89169\%. Nilai MAPE sebesar 2,89169\% kurang dari 10\% yang berarti kinerja model sangat baik.

\section{DAFTAR PUSTAKA}

Badan Pusat Statistik. 2012. Badan Pusar Statistik. Diambil kembali dari www.bps.go.id/ Bank Indonesia. 2001. Bank Indonesia. Diambil kembali dari www.bi.go.id/

Eubank, R. L. 1988. Spline Smoothing and Nonparametric Regression. Texas: Departement of Statistics Southern Methodist Dallas University.

Eubank, R. L. 1999. Nonparametric Regression and Spline Smoothing. New York: Marcel Dekker, Inc.

Gujarati, D. 2006. Ekonometrika Dasar.. Jakarta: Erlangga.

Hardle, W. 1994. Applied Nonparametric Regression. Cambridge University

Johnson, R. A., \&Wichern, D. W. 2007. Applied Multivariate Statistical Analysis. USA: Pearson Education.

Riskiyanti, R. 2010. Analisis Regresi Multivariat Berdasarkan Faktor-Faktor yang Mempengaruhi Derajat Kesehatan di Provinsi Jawa Timur. Jurnal Sains dan Seni ITS, Vol 5, No 2.

Ruppert, D., Wand, M. P., Carroll, R. J. 2003. Cambridge Series in Statistical and Probabilistic Mathematics: Semiparametric Regression. New York: Cambridge University Press.

Suparti, Santoso, R., Prahutama, A., Devi, A. R. 2018. Regresi Nonparametrik.Ponorogo: Wade Group. 
Supranto, J. 1988. Teori dan Aplikasi Statistik. Edisi Lima. Jakarta: Erlangga.

Welsh, A. H. and Yee, T. W., 2006, Local Regression for Vector Responses,Journal of Statistical Planning and Inference 136; 2006, 3007 - 3031.

Wu, H., \& Zhang, J. T. 2006. NonparametricRegression Method For Longitudinal Data Analysis. Canada: Jonh and Willey Son Inc. 